\title{
Comparing different farming habitats for mid-water rope nurseries to advance coral restoration efforts in the Maldives
}

\author{
Inga Dehnert $^{\text {Corresp., } 1,2}$, Luca Saponari $^{3}$, Paolo Galli $^{1,2}$, Simone Montano $^{1,2}$ \\ ${ }^{1}$ Department of Earth and Environmental Sciences (DISAT), University of Milan-Bicocca, Milan, Italy \\ 2 MaRHE Center (Marine Research and High Education Center), Magoodhoo Island, Faafu Atoll, Republic of Maldives \\ 3 The Centre for Environment \& Education, Nature Seychelles, Mahe, Republic of Seychelles \\ Corresponding Author: Inga Dehnert \\ Email address: inga.dehnert@unimib.it
}

The need for comprehensive and effective coral restoration projects, as part of a broader conservation management strategy, is accelerating in the face of coral reef ecosystem decline. This study aims to expand the currently limited knowledge base for restoration techniques in the Maldives by testing the performance of mid-water rope nurseries in a lagoon and a reef habitat. We examined if different coral farming habitats impacted fragment survival, health and growth of two coral genera and how the occurrence of mutualistic fauna, predation and disease influenced coral rearing success. Therefore, two nurseries were stocked with a total of 448 Pocillopora verrucosa and 96 Acropora spp. fragments, divided into different groups (four Pocillopora groups: lagoon nursery at 5m; reef nursery at 5, 10 and 15m; two Acropora groups: lagoon nursery at $5 \mathrm{~m}$ and reef nursery at $5 \mathrm{~m}$ ). Eight fragment replicates from the same donor colony (Pocillopora genets: $\mathrm{N}=14$, Acropora genets $\mathrm{N}=6$ ) were used in each group and monitored for one year. Our results show that fragment survival was high in both farming habitats (>90\%), with $P$. verrucosa surviving significantly better in the lagoon and Acropora spp. surviving and growing significantly faster in the reef nursery. $P$. verrucosa growth rates were similar between reef and lagoon habitat. Different rearing depths in the reef nursery had no impact on the survival of $P$. verrucosa but coral growth decreased considerably with depth, reducing fragments' ecological volume augmentation and growth rates by almost half from 5 to $15 \mathrm{~m}$ depth. Further, higher fish predation rates on fragments were recorded on the reef, which did not impact overall nursery performance. Mutualistic fauna, which correlated positively with fragment survival, was more frequently observed in the lagoon nursery. The occurrence of disease was noted in both habitats, even though implications for fragment health were more severe in the lagoon. Overall, our study demonstrates that lagoon and reef nurseries are suitable for rearing large numbers of coral fragments for transplantation. Nevertheless, we recommend to consider the specific environmental 
conditions of the farming habitat, in particular water quality and year-round accessibility, in each case and to adjust the coral farming strategy accordingly. We hope that this novel research encourages the increased application of mid-water rope nurseries for 'coral gardening' to advance coral reef recovery and climate resilience in the Maldives. 


\section{Comparing different farming habitats for mid-water rope} 3 nurseries to advance coral restoration efforts in the Maldives

$8{ }^{1}$ Department of Earth and Environmental Sciences (DISAT), University of Milan-Bicocca, 9 Milan, Italy

$10{ }^{2}$ MaRHE Center (Marine Research and High Education Center), Magoodhoo Island, Faafu 11 Atoll, Republic of Maldives

$12{ }^{3}$ Nature Seychelles, The Centre for Environment \& Education, Mahe, Republic of Seychelles 13

14 Corresponding Author:

15 Inga Dehnert ${ }^{1,2}$

16 Piazza della Scienza, Milan, 20126, Italy

Email address: inga.dehnert@unimib.it 
20

21

22

23

24

25

26

27

28

29

30

31

32

33

34

35

36

37

38

39

40

41

42

43

44

45

46

47

48

49

50

51

52

53

54

55

56

57

58

59

\section{Abstract}

The need for comprehensive and effective coral restoration projects, as part of a broader conservation management strategy, is accelerating in the face of coral reef ecosystem decline.

This study aims to expand the currently limited knowledge base for restoration techniques in the Maldives by testing the performance of mid-water rope nurseries in a lagoon and a reef habitat. We examined if different coral farming habitats impacted fragment survival, health and growth of two coral genera and how the occurrence of mutualistic fauna, predation and disease influenced coral rearing success. Therefore, two nurseries were stocked with a total of 448 Pocillopora verrucosa and 96 Acropora spp. fragments, divided into different groups (four Pocillopora groups: lagoon nursery at 5m; reef nursery at 5, 10 and 15m; two Acropora groups: lagoon nursery at $5 \mathrm{~m}$ and reef nursery at $5 \mathrm{~m}$ ). Eight fragment replicates from the same donor colony (Pocillopora genets: N=14, Acropora genets N=6) were used in each group and monitored for one year.

Our results show that fragment survival was high in both farming habitats $(>90 \%)$, with $P$. verrucosa surviving significantly better in the lagoon and Acropora spp. surviving and growing significantly faster in the reef nursery. P. verrucosa growth rates were similar between reef and lagoon habitat. Different rearing depths in the reef nursery had no impact on the survival of $P$. verrucosa but coral growth decreased considerably with depth, reducing fragments' ecological volume augmentation and growth rates by almost half from 5 to $15 \mathrm{~m}$ depth. Further, higher fish predation rates on fragments were recorded on the reef, which did not impact overall nursery performance. Mutualistic fauna, which correlated positively with fragment survival, was more frequently observed in the lagoon nursery. The occurrence of disease was noted in both habitats, even though implications for fragment health were more severe in the lagoon.

Overall, our study demonstrates that lagoon and reef nurseries are suitable for rearing large numbers of coral fragments for transplantation. Nevertheless, we recommend to consider the specific environmental conditions of the farming habitat, in particular water quality and yearround accessibility, in each case and to adjust the coral farming strategy accordingly. We hope that this novel research encourages the increased application of mid-water rope nurseries for 'coral gardening' to advance coral reef recovery and climate resilience in the Maldives.

\section{Introduction}

Coral reef restoration has become an increasingly applied tool and internationally adapted approach to counteract the worldwide degradation of coral reefs (United Nations Environment Assembly 2019; Boström-Einarsson et al., 2020). While sometimes criticized for not tackling the underlaying problem and therefore using limited conservation resources inefficiently (Bellwood et al., 2019; Morrison et al., 2020), supporters argue that, in concert with other environmental measures, rigorously managed local restoration projects can improve social, economic and ecological resilience, and therefore increase the odds for reef survival and recovery (Hein et al., 
60

61

62

63

64

65

66

67

68

69

70

71

72

73

74

75

76

77

78

79

80

81

82

83

84

85

86

87

88

89

90

91

92

93

94

95

96

97

98

2019, 2021; Duarte et al., 2020). Such projects may also prove valuable in the face of global threats that are often beyond the level of local or even national control.

The low-lying archipelago of the Maldives, a country that owes its existence to the 26 natural coral atolls, is on the forefront of experiencing the adverse effects of climate change. Over the next decades, the nation's mere existence will depend on its ability to protect its population, infrastructure, economy and coral reef ecosystem from the risks posed by warming oceans, sea level rise and severe weather events (Sovacool, 2012; Storlazzi et al., 2018). Maldivian coral reefs are essential for the country's economy, that heavily relies on tourism and fisheries (Statistical Yearbook of Maldives, 2020). Nevertheless, Maldivian reefs have already seen considerable degradation following several mass bleaching events (Tkachenko, 2015; Perry \& Morgan, 2017) along with other threats such as pollution, corallivores and disease outbreaks (Jaleel, 2013; Montano et al., 2016; Saponari et al., 2018; Montalbetti et al., 2019). Monitoring data from the most recent mass-bleaching in 2016 reported that $73 \%$ of shallow water corals were bleached across the Maldives (Ibrahim et al., 2016). Subsequent changes in Maldivian coral community structure included the disproportionately high mortality of reef-building Acropora species as well as an observed shift from mature populations towards small and medium sized colonies (Pisapia et al., 2019). Preserving and restoring the resilience of Maldivian coral reefs, through environmental protection and active restoration should therefore be of immediate priority to brace the archipelago against climate change. After all, healthy and structurally complex reefs can, for example, provide protection against coastal erosion (Harris et al., 2018) and may even help islands to grow upwards in response to sea level rise (Masselink et al., 2020). In the past, restoration projects in other locations have demonstrated the ability to mitigate the continued degradation of coral reefs. For example, large scale, long-term reef restoration was successfully conducted in Indonesia, following physical reef degradation from blast fishing and other human activities. Coral cover increased significantly following rehabilitation treatment to stabilize substrate in Komodo National Park (Fox et al., 2019) and the deployment of artificial structures with attached coral fragments increased not only live coral cover by more than $50 \%$, but also demonstrated minimal subsequent bleaching impacts despite warm waters and continued disturbances (Williams et al., 2019).

Surprisingly, coral reef restoration activities are not widely applied in the Maldives. Peerreviewed studies of direct transplantation and concrete blocks as artificial reef structures date back to the 1990s (Clark \& Edwards, 1994, 1995). Currently, the dominant form of restoration appears to be the application of metal frames, also known as spiders, as artificial reefs, a practice that can be easily applied in a resort setting and also serves as an educational tool (Edwards et al., 2010; Hein et al., 2019). However, larger active restoration projects applying the 'gardening concept' of a farming and an outplanting phase (Rinkevich 1995, 2000; Epstein et al. 2001) are relatively uncommon and undocumented, especially in community or resort-based projects. 
99 Mid-water floating nurseries and in particular rope nurseries, allow small, fragmented corals to 100 grow fast under optimal conditions due to increased light and water flux, reduced sedimentation 101 and overgrowth as well as protection from demersal predators (Shafir et al., 2006; Levy et al., 102 2010). They have proven an effective tool in gardening projects around the world in order to 103 increase fragment survival and growth while continuously building a bigger re-sourcing and 104 farming stock (Shafir \& Rinkevich, 2010; Frias-Torres et al., 2018; Bayraktarov et al., 2020). 105 When deciding on the in-situ nursery location, it is recommended to consider water quality, 106 depth, shelter and accessibility while also aiming for similar environmental conditions of the 107 targeted transplantation site (Frias-Torres et al., 2018). Therefore, nurseries are often placed in 108 shallow lagoons, where the growing fragments are protected from the forces of currents and 109 weather as well as corallivorous reef predators (Levy et al., 2010). The nurseries soon turn into 110 floating ecosystems by attracting fish assemblages which can reduce cleaning requirements and

111

112

113

114

115

116

117

118

119

120

121

122

123

124

125

126

127

128

129

130

131

132

133

134

135

136

137

138 costs as they consume biofouling (Shafir et al., 2006; Shafir \& Rinkevich, 2010). However, reef environments typically already host diverse fish communities that could provide cleaning services or even pose a predation risk (Frias-Torres et al., 2015; Seraphim et al., 2020). On the reef, environmental conditions are also more likely to resemble the future transplantation site, while nursey structures are more exposed to natural forces and likely more difficult to construct. Selecting a suitable rearing environment is therefore a crucial factor for the success of any coral gardening project and requires careful, knowledge-based assessment. In the Maldives, coral reefs and their lagoon habitats cover approximatively $20 \%$ of the county's Territorial Sea (Naseer \& Hatcher, 2004). Yet potential nursery sites may vary considerably in their characteristics and decision driving evidence remains to be verified for this part of the Indian Ocean.

This study provides an in-depth comparison of the performance of mid-water rope nurseries in a lagoon and reef habitat in the Maldives over a one-year monitoring period for the first time. We assessed the survival, health and growth of the same genotypes of Pocillopora verrucosa and Acropora spp. fragments to better understand the positive and negative implications of these farming environments and their specific challenges. With our findings we hope contribute to the informed decision making in active restoration projects and encourage the wider application of this technique in the Maldives, particularly in tourist resort settings.

\section{Materials \& Methods}

\section{Study Design}

This study assessed coral nursery farming performance in two habitats, an inner atoll reef and a sheltered lagoon environment, on Athuruga Resort Island (3 $\left.{ }^{\circ} 53^{\prime} 14^{\prime \prime} \mathrm{N} 72^{\circ} 48^{\prime} 59^{\prime \prime} \mathrm{E}\right)$ in Alif Dhaal atoll, in the Republic of Maldives (Fig. 1a). Two mid-water rope nurseries, one in each location, were simultaneously stocked in February 2020 and fragment development was monitored for one year. The lagoon nursery (LN) was situated away from daily resort activities, about 500m from the main island, anchored at $10 \mathrm{~m}$ depth and comprised horizontally suspended $10 \mathrm{~m}$ long coral 
139 ropes attached to PVC pipes at $5 \mathrm{~m}$ depth (Fig. 1b). Athuruga's large lagoon, measuring 140 approximately $1200 \mathrm{~m}$ from West to East and $650 \mathrm{~m}$ from North to South, is surrounded by a reef 141 rim and only connects via a narrow artificial channel to the inner Atoll Sea. No currents are 142 experienced here and visibility is typically low. The lagoon floor is characterized by a sandy 143 bottom with an abundant echinoderm fauna, in particular various sea cucumber species and large 144 seastars such as the corallivorous Culcita sp.. The isolated reef patches that, following the 2016 145 mass bleaching, mainly comprise of dead corals and some living Porites colonies concentrate the 146 limited fish life. The reef nursery $(\mathrm{RN})$ was placed parallel to the island's southern house reef, 147 that exhibits a steep slope in this area. Here, the once abundant and diverse live coral cover has 148 also been severely reduced to less than 5\%, following the latest bleaching and an outbreak of the corallivorous seastar Acanthaster planci (Saponari et al., 2018, 2021), with some larger massive coral colonies and a comparably abundant reef fish community remaining. The RN was anchored at $20 \mathrm{~m}$ depth, about 5-10 $\mathrm{m}$ away from the reef slope and a more streamlined design (no PVC pipes) was chosen to account for the increased exposure to slight to moderate currents on the reef. Horizontally suspended, $14 \mathrm{~m}$ long coral ropes were directly attached to the vertical anchoring ropes at three different depths $(5,10$ and $15 \mathrm{~m})$ (Fig. 1c).

155

156

For the purpose of this study, the two nurseries were stocked with a total of 544 experimental fragments from two coral genera, namely Pocillopora and Acropora. Pocillopora verrucosa fragments derived from 14 donor colonies (12-18cm diameter) that were previously reared in the two mid-water rope nurseries on Athuruga (hereafter referred to as

160

161

162

163

164

165

166

167

168

169

170

171

172

173

174

175

176

177

178 lagoon or reef 'donor farming habitat' of experimental fragments). These donors were originally collected in 2018 from two natal sites with similar conditions to Athuruga's farming habitats. Pocillopora donors growing in the reef nursery originated from artificial substrate on Athuruga reef (i.e., mooring lines) and were reared between 7 and $18 \mathrm{~m}$ depth. Donors growing in the lagoon nursery at $5 \mathrm{~m}$ were originally collected from the shallow back reef of Thudufushi. Island $\left(3^{\circ} 47^{\prime} 05^{\prime \prime} \mathrm{N} 72^{\circ} 43^{\prime} 49^{\prime \prime} \mathrm{E}\right)$, since Athuruga lagoon did not offer sufficient live corals for nursery stocking. All donor colonies were assumed to be of different genotype as they were initially collected as corals of opportunity spaced more than 10m apart (Edwards \& Gomez, 2007; Foster et al., 2007). In order to prevent any bias in nursery comparison resulting from possible habituation to the farming habitat or translocation to a different habitat, seven 'reef donor' and seven 'lagoon donor' colonies were used for the experiment (see supplementary Fig. S1 for experimental design graphic).

To compare coral farming performance between the lagoon and the reef habitat and for different depths in the RN, a total of 448 P. verrucosa fragments were stocked, divided into four groups (Poc_LN_5m; Poc_RN_5m; Poc_RN_10m; Poc_RN_15m) according to nursery habitat and rearing depth. Each of the 14 donor colonies were fragmented in 32 similar sized fragments, ranging from $3-10 \mathrm{~cm}$ in diameter depending on the selected fragmentation size for each donor colony. Then, a subset of 8 fragments was used for each study group, resulting in a total of 112 
179 fragments per group with the same distribution of fragment genotypes and sizes. Fragmentation

180 of $P$. verrucos $a$ donor colonies from the $\mathrm{RN}$ and $\mathrm{LN}$ and restocking occurred on the nursery site 181 and underwater using SCUBA equipment. To limit handling stress and damage, the stocked 182 ropes were immediately reattached to the nurseries. Fragments that required translocation to a 183 different rearing habitat were continuously submerged in separate containers and transported by 184 divers the same day. Excess fragments were reared on separate ropes in the nurseries and 185 excluded from the study.

186

Acropora fragments were directly collected as corals of opportunity from a nearby reef $\left(3^{\circ} 48^{\prime} 51^{\prime \prime N} 72^{\circ} 45^{\prime} 10^{\prime \prime E}\right)$ from less than $5 \mathrm{~m}$ unshaded depth. Six suitable colonies were selected based on their fragmentable size (15-20 cm in diameter), similar arborescent branching morphology and distance between them $(>30 \mathrm{~m})$ to increase genetic diversity. As available

191

192

193

194

195

196

197

198

199

200

201

202

203

204

205

206

207

208

209

210

211

212

213

214

215

216

217

218 Acropora spp. fragments possibly comprise more than one species, all comparisons are made at the genus level. The donor colonies were kept in shaded and spacious containers filled with fresh seawater and transported to Athuruga within one hour, followed by the same fragmentation and stocking procedure as for $P$. verrucosa. In the nurseries, Acropora spp. fragments represented two study groups of 48 fragments each, growing at $5 \mathrm{~m}$ depth in the $\mathrm{LN}$ and the $\mathrm{RN}$ (Acr_LN_5m; Acr_RN_5m). Again, subsets of 8 similar sized fragments (3-11 cm diameter) per donor colony were used, likely representing six different genotypes.

A monthly monitoring and maintenance protocol was established for a one-year farming period. The protocol was interrupted due to Covid-19 from months three to eight, resulting in a total of seven surveys (T1, T2 and T3-T7 post interruption) and three growth measurements at stocking (T0), post interruption (T3) and after one year (T7) for all fragments. Water temperature was recorded at $5 \mathrm{~m}$ depth during each dive using a Suunto dive computer.

\section{Data Analysis}

The status of nursery-grown experimental fragments was analyzed applying the following parameters suggested by Frias-Torres et at. (2018): 'Survival' was determined as a binary condition ('alive' and 'dead') for each treatment group, habitat and genus and was compared using the chi-square test of independence. Fragment 'Condition' (see Fig. 2) was recorded as a categorical variable for each survey, distinguishing between fragments with $100 \%$ living tissue (H3), more than $50 \%$ of coral tissue is alive (H2), and less than $50 \%$ living tissue on the fragment $(\mathrm{H} 1)$ and is shown in percentage for each category and fragment group. It was further noted, whether fragments showed any signs of bleaching, disease or algae overgrowth. Predation incidents were recorded when fresh bitemarks or predation scars were evident on the fragments. The presence of any sessile corallivores, mutualists or any other visible fauna associated with the coral was also recorded. The percentage of fragments with diseased tissue was calculated for the last survey (T7), while associated fauna and predation rates were calculated as percentage of affected corals per study group for each survey and averaged across the study period. For 
219 predation and disease calculations dead fragments were excluded. Differences between habitats

220

221

222

223

224

225

226

227

228

229

230

231

232

233

234

235

236

237

238

239

240

241

242

243

244

245

246

247

248

249

250

251

252

253

254

255

256

257

258

and depths as well as associations between mutualistic fauna and fragment survival were analyzed using the chi-squared test, with a post hoc residual analysis for different depth groups with a Bonferroni adjusted alpha level of 0.008 for the predation analysis.

Fragment initial size at stocking and 'Growth' was calculated for all fragments as 'Ecological volume' (EV) by taking three measurements to the nearest mm using a Vernier caliper, where:

$$
\mathrm{EV}=\pi \mathrm{r} 2 \mathrm{~h} \text {, where } \mathrm{r}=(\mathrm{w}+\mathrm{l}) / 4
$$

with ' $h$ ' representing the longest linear colony diameter of the three perpendicular measurements ( $\mathrm{h}=$ height, w=width, l=length; see Shafir et al., 2006). The difference in EV at the start (T0) and the end (T7) of the study was compared using the Wilcoxon signed rank test and used to compute 'Size augmentation' and 'Daily growth rates' for all living fragments in each group. Growth rate data was natural log transformed to meet the homogeneity of variance assumption and analyzed using an ANOVA with Turkey's post hoc test.

In addition, the relationship between fragments' initial size (EV at T0) and the subsequent growth rate for $P$. verrucosa fragments was investigated using a Pearson correlation to obtain a better understanding of optimal stocking size for this species.

The experimental design further allowed to test for any differences between $P$. verrucosa fragments originating from 'reef reared' and 'lagoon reared' donors (i.e., whether fragments from lagoon or reef reared donor colonies grew significantly different in the RN and the LN farming habitat). Therefore, mean differences in growth rates between fragments originating from reef and lagoon farming habitats were compared within each study group using the MannWhitney test.

All statistical analysis was performed using SPSS ver. 27 (IBM, New York) and all data is represented as arithmetic means \pm standard error. Non-parametric test statistics were used when the normality assumption was violated.

\section{Results}

\section{Survival}

Overall, the survival of the experimental stock $(\mathrm{N}=544)$ was high $(91 \%)$ after one year (T7) with differences between Pocillopora verrucosa (94\%; N=448) and Acropora spp. (89\%; N=98) fragment survival being marginally non-significant $\left(\chi^{2}(1, \mathrm{~N}=544)=3.59, p=0.058\right)$. For $P$. verrucosa the survival rate was above $90 \%$ for all four groups with the highest survival recorded in the LN (99\%), which was significantly different from the RN survival $\left(\chi^{2}(1, N=448)=6.95\right.$, $p=0.008)$. Here, the average survival rate for all depths was $92 \%$ and rearing depth had no significant effect on survival $\left(\chi^{2}(2, \mathrm{~N}=336)=1.334, p=0.513\right.$; see Table 1$)$. In contrast, the survival of Acropora spp. fragments, all growing at $5 \mathrm{~m}$ depth, was significantly higher in the RN $(96 \%)$ than in the LN (81\%; see Table 2$)\left(\chi^{2}(1, N=96)=5.031, p=0.025\right)$.

Peer) reviewing PDF | (2021:08:65161:2:0:NEW 4 Jan 2022) 
260

261

262

263

264

265

266

267

268

269

270

271

272

273

274

275

276

277

278

279

280

281

282

283

284

285

286

287

288

289

290

291

292

293

294

295

296

297

298

\section{Condition}

Similarly, the majority of $P$. verrucosa fragments (RN: $88 \%$; LN: $96 \%$ ) were fully alive (H3) after one year (T7) with only a few partially alive corals (H2 and H1) found in each RN group $(\mathrm{N}=4$ at $5 \mathrm{~m} ; \mathrm{N}=6$ at $10 \mathrm{~m}$ and $\mathrm{N}=2$ at $15 \mathrm{~m}$; see Fig. 3 ). In the $\mathrm{LN}$ only 3 fragments had suffered partial mortality (H2). No signs of disease were observed in P. verrucosa stock in the $\mathrm{LN}$, while $3.6 \%$ of RN fragments were diseased with a rapid tissue loss syndrome (see Moriarty et al., 2020 ) at the last survey ( $\mathrm{N}=3$ at $5 \mathrm{~m}, \mathrm{~N}=6$ at $10 \mathrm{~m}$ and $\mathrm{N}=2$ at $15 \mathrm{~m}$; Table 1 ).

For Acropora spp. fragment health was more variable. In the RN $63 \%$ of the fragments were fully alive, while $33 \%$ had suffered partial mortality ( $\mathrm{H} 2=23 \%$; $\mathrm{H} 1=10 \%$ ) due to algae overgrowth. In the LN, the spread of 'White Syndrome' disease (see Montano et al. 2012) had considerably impacted fragment condition (H2: $46 \%$; H1: 35\%; see Fig. 3) with no fully alive fragments remaining after one year and $18 \%$ of the living stock showing diseased tissue at $\mathrm{T} 7$, which was also the main cause of death in this group (Table 2).

On $P$. verrucosa fragments the average predation rate was significantly lower in the $\mathrm{LN}$ ( $37 \pm$ $18 \%)$ than in the $\mathrm{RN}(47 \pm 14 \%)\left(\chi^{2}(1, \mathrm{~N}=3481)=13.504, p<0.001\right)$, where predation decreased significantly from $5 \mathrm{~m}$ ( 423 predation incidents in total) to $15 \mathrm{~m}$ depth ( 245 predation incidents; see Table 1) $\left(\chi^{2}(2, \mathrm{~N}=2592)=90.483, p<0.001\right)$. In the $\mathrm{RN}$, predation events were also more consistent throughout the study period (in 6 out of 7 surveys), while in the LN predation on fragments was only recorded in three surveys. Predation on Acropora spp. was only recorded once on two fragments in the RN. Corals only showed fish predation marks in both habitats, which never made up more than $5 \%$ of the fragment's surface and visibly healed between surveys.

Of the fragment inhabiting fauna, guard crabs of the genus Trapezia were most frequently observed (90\%; $\mathrm{N}=475)$, while other small crabs, shrimps and fish made up the remaining $10 \%$. Coral associated fauna was significantly higher in the $\mathrm{LN}\left(\chi^{2}(1, \mathrm{~N}=3584)=193.24, p<0.001\right)$. Specifically, associated fauna was on average most frequently observed on $P$. verrucosa fragments in the $\mathrm{LN}(26 \pm 7 \%$ ), while only found in $7 \pm 2 \%$ of RN fragments. Similarly, $23 \pm 5 \%$ of Acropora spp. fragments in the LN were associated with fauna while in the RN it was only $4 \pm$ $2 \%$. A significant positive relationship between $P$. verrucosa survival and Trapezia crabs occurrence was found $\left(\chi^{2}(1, \mathrm{~N}=3584)=9.674, p=0.002\right)$.

Temperature or stress induced bleaching was not an issue during the rearing period and water temperatures never exceeded $30{ }^{\circ} \mathrm{C}$ at $5 \mathrm{~m}$ depth in either habitat. Temporary bleaching of the upper fragment tissue was only observed in 3 fragments (1 Poc at LN;1 Poc and 1 Acr in RN) during the study. Brown algae (Sargrassum sp.) overgrowth was most noticeable on Acropora fragments in the RN, where 10 fragments had suffered partial tissue damage at T3 due to the interrupted maintenance schedule. In contrast, blue-green algae, identified in the field as mainly Schizothrix calcicola were prevalent on the LN structure, but did not overgrow living fragments. 


\section{Growth}

300 Fragment size was calculated as Ecological Volume, which increased significantly for all groups

301

302

303

304

305

306

307

308

309

310

311

312

313

314

315

316

317

318

319

320

321

322

323

324

325

326

327

328

329

330

331

332

333

334

335

336

337

338 during the one-year survey period (Fig. 4). The largest EV size increase (2195\%) was observed in $P$. verrucosa fragments in the LN, which grew significantly from $41 \pm 2 \mathrm{~cm}^{3}$ to $905 \pm 31 \mathrm{~cm}^{3}$ in 371 days $(Z(\mathrm{~N}=111)=-9.15, p<0.001$; Fig.4a $)$. This was closely followed by fragments growing also at $5 \mathrm{~m}$ on the RN, which increased by $1957 \%$ (from $40 \pm 3 \mathrm{~cm}^{3}$ to $780 \pm 31 \mathrm{~cm}^{3}$; $Z(\mathrm{~N}=101)=-8.72, p<0.001)$. On the $\mathrm{RN}$ fragment size augmentation (Table 1) decreased with depth. At $10 \mathrm{~m}$ depth fragment increase was $1364 \%\left(43 \pm 3 \mathrm{~cm}^{3}\right.$ to $580 \pm 22 \mathrm{~cm}^{3} ; Z(\mathrm{~N}=102)=-$ $8.77, p<0.001)$ while at $15 \mathrm{~m}$ the $\mathrm{EV}$ increase was reduced to a $1127 \%$ increase $(38 \pm 4 \mathrm{~cm}$ to 390 $\left.\pm 40 \mathrm{~cm}^{3} ; Z(\mathrm{~N}=106)=-8.94, p<0.001\right)$.

Therefore, daily growth rates for $P$. verrucosa varied significantly between fragment groups $(F(3,416)=36.284, p<0.001)$. Post hoc testing revealed that there was no significant difference in daily growth rates between the lagoon $(\mathrm{M}=0.08 \pm .005)$ and the reef $(\mathrm{M}=0.07 \pm .004)$ at $5 \mathrm{~m}$ $(p=0.848)$. However, on the $\mathrm{RN}$ daily growth rates (see Table 1) varied significantly between the three rearing depths, with shallower depths showing faster growth rate $(p \leq 0.001)$.

EV also increased for both Acropora spp. groups (Fig.4b) during the one-year (353 days) farming period, in the $\mathrm{LN}$ by $738 \%$ (from $40 \pm 5 \mathrm{~cm}^{3}$ to $295 \pm 38 \mathrm{~cm}^{3} ; Z(\mathrm{~N}=38)=-5.37, p<0.001$ ) and in the $\mathrm{RN}$ by $1098 \%$ (from $36 \pm 4 \mathrm{~cm}^{3}$ to $390 \pm 40 \mathrm{~cm}^{3} ; Z(\mathrm{~N}=46)=-5.91, p<0.001$ ). Size augmentation and daily growth rates (Table 2 ) varied significantly between the LN and the RN at $5 \mathrm{~m}(Z(\mathrm{~N}=84)=579, p=0.008)$, with fragments growing much faster on the reef.

\section{Initial size}

Average initial size at stocking for all $P$. verrucosa fragments was $5.22 \pm 1.1 \mathrm{~cm}$ in diameter $(\mathrm{h})$, ranged from 2.7 to $10.0 \mathrm{~cm}$. A significant negative correlation between initial size $\mathrm{EV}$ and subsequent growth rate was found, with smaller fragments showing a faster growth rate $(r(418)=-0.56 ; p<0.001)$. This pattern was even more evident when analyzing treatment groups separately to account for the effect of depth (LN_5m: $r(109)=-0.65 ; \mathrm{RN} \_5 \mathrm{~m}: r(99)=-0.65$; $\mathrm{RN} \_10 \mathrm{~m}: r(100)=-0.63 ; \mathrm{RN} \_15 \mathrm{~m}: r(104)=-0.68$; all $p<0.001$; see Fig. 5).

\section{Donor farming habitat}

To investigate possible impacts of different donor farming habitats on fragments' growth rates in the two nurseries, the observed effect of initial size had to be controlled for first. Therefore, fragments from two reef farmed donor colonies with the two smallest mean stocking sizes as well as fragments from two lagoon farmed donor colonies with the largest stocking means were removed from the analysis. The remaining 141 fragments from 'reef farmed donors' and 156 fragments from 'lagoon farmed donors' were non-significantly different in stocking size at T0 $(Z(\mathrm{~N}=320)=12419.5, p=0.646)$.

Growth rate comparison for these fragments at $\mathrm{T} 7$ revealed that $P$. verrucosa fragments that derived from reef donor colonies $\left(\mathrm{M}_{\text {Reef }}=0.0597 \pm .003\right)$ grew significantly faster than fragments from lagoon farmed donor colonies $\left(\mathrm{M}_{\mathrm{Lag}}=0.0478 \pm .003\right)(Z(\mathrm{~N}=297)=8322, p<0.001)$. This was 
339

340

341

342

343

344

345

346

347

348

349

350

351

352

353

354

355

356

357

358

359

360

361

362

363

364

365

366

367

368

369

370

371

372

373

374

375

376

377

378

also the case when comparing daily growth rates for each study group separately (Fig. 6). In all but the RN_5m group fragments of reef farmed donors grew significantly faster than fragments that derived from lagoon donors, including the lagoon group (Poc_LN_5m), where fragments originating from reef farmed donors grew faster in the new habitat than fragments derived from lagoon farmed donor colonies $(Z(\mathrm{~N}=79)=577, p=0.047)$.

\section{Discussion}

This study conducted a direct comparison and comprehensive assessment of mid-water rope nursery performance in a lagoon and a reef habitat in the Maldives for the first time. Our evaluations are based on fragment survival and growth as well as the occurrence of predation, disease and mutualistic fauna.

In both coral farming habitats, fragment survival was very high (81-99\%) throughout the oneyear study period. Similar survival rates have been reported, for example, from the Caribbean (85-96\% for Acropora cervicornis after 12 months in in-situ nurseries; Schopmeyer et al. 2017) or the Philippines (96.4 $\pm 2.2 \%$ for Pocillopora damicornis after 10 months in a rope nursery; Levy et al., 2010). High fragment survival is critical for the success of the labor-intensive rearing phase of the coral gardening approach, so sufficient healthy colonies are available for the subsequent transplantation phase (Edwards \& Gomez, 2007; Frias-Torres et al., 2018). However, direct comparison revealed that Pocillopora fragments' survival was significantly higher in the LN, while Acropora fragments survived better in the RN. Closer inspection revealed that fragment survival and condition of both genera were affected differently by the spread of disease, which appeared to be coral genus and habitat specific, as only Pocillopora was affected on the reef while only Acropora was affected in the lagoon. For Acropora fragments, the negative effect of disease was also clearly noticeable when comparing growth, which was twice as fast in the disease-free RN stock. These findings highlight the need to investigate coral diseases in coral restoration further, in particular possible transmission routes, time and density dependences in nurseries and mitigation measures. In this context, water quality and human induced pollution, in particular when operating in a resort setting, also require further attention. Disease outbreaks can significantly impact coral farming success and there is an additional danger of introducing disease to transplantation sites (Moriarty et al., 2020).

Coral predation is another factor that can hinder coral restoration success (Miller et al., 2014; Koval et al., 2020). Our study confirms that mid-water rope nurseries are very effective in keeping corals safe from known Maldivian corallivores such as the snail Drupella sp. or the starfish Culcita sp., which are regularly encountered in both habitats (Montalbetti et al., 2019; Saponari et al., 2021). All recorded predation incidents were from fish and hence they were more commonly observed on the reef, as one would expect. Nevertheless, predation scars were small and healed between survey intervals, therefore not directly impacting fragment condition. It 
379 should further be tested, if predatory fish occurrence could be reduced on the reef by placing the

380

381

382

383

384

385

386

387

388

389

390

391

392

393

394

395

396

397

398

399

400

401

402

403

404

405

406

407

408

409

410

411

412

413

414

415

416

417

418

nursery structure further away from the safety of the reef slope (here only $5-10 \mathrm{~m}$ between structure and reef), if seafloor topography allows it.

We also investigated the occurrence of mutualistic fauna in the nurseries, in particular guard crabs, which can have positive impacts on coral health (Glynn, 1987; Stewart et al., 2006). The many benefits of hosting mutualistic fauna such as damselfish, decapods and hydrozoans have been widely studied, showing that it can reduce corallivory, sedimentation, predation, disease and even coral bleaching (McKeon \& Moore, 2014; Montano et al., 2017; Chase et al., 2018, 2020). In line with these findings, our results suggest a positive correlation between guard crab presence and fragment survival. Trapezia sp. was first recorded in the coral stock after 8 months (T3), when fragments had reached a suitable size and branch complexity to host guard crabs. The percentage of fauna hosting corals was significantly higher in the lagoon, for both Acropora and Pocillopora fragments. There could be two, not mutually exclusive explanations for this observation. First, Trapezia sp. predators such as small reef inhabiting wrasses were never encountered during the surveys in the lagoon, while they have been regularly observed on the $\mathrm{RN}$ during maintenance work, which could indicate a higher predator abundance on the reef. In fact, increased predation pressure has previously been linked to reduced abundance of mutualistic decapods in Pocillopora colonies (Stier \& Leray, 2014). Second, the LN hosted additional, older Pocillopora stock that was already populated by Trapezia crabs and hence population of the new fragments could have been facilitated. Movement of guard crabs between coral hosts to increase their reproductive success has been well documented (Castro, 1978) and deserves further attention. For instance, rearing fragments of mixed-age could be used to increase the abundance of mutualistic fauna and improve coral health in farming stocks.

Apart from coral survival, growth can be considered an important indicator of coral-farming success as it determines rearing time in the nurseries and therefore influences cost effectiveness and eventually restoration outcome (Edwards et al., 2010). Corals can reduce mortality risk by growing to a certain size (Connell, 1973; Highsmith, 1982), hence several studies have looked at fragment size and depth as variables in coral nurseries (Forsman et al., 2006; Soong \& Chen, 2003). Direct comparison between the LN and the RN showed that at shallow depth, $P$. verrucosa fragments grew at a similar rate indicating no apparent difference in farming environments. The insignificantly slower growth rate at $5 \mathrm{~m}$ in the $\mathrm{RN}$ is likely a result of the longer coral ropes that were pulled downwards (up to $7 \mathrm{~m}$ depth at the lowest point) as coral weight increased over time, even if this was counteracted with additional buoyancy devices. Although rearing depth had no effect on survival, $P$. verrucosa growth rates decreased by $27 \%$ from 5 to 10 and another $21 \%$ from 10 to $15 \mathrm{~m}$ on the reef as light levels decrease. Light availability is an important environmental parameter determining coral growth and typically reflected in the abundance of fast-growing corals in shallow depths (Gladfelder et al., 1978; Grigg 2006) and the increased calcification rate in shallow waters (Huston 1985), for which

PeerJ reviewing PDF | (2021:08:65161:2:0:NEW 4 Jan 2022) 
419

420

421

422

423

424

425

426

427

428

429

430

431

432

433

434

435

436

437

438

439

440

441

442

443

444

445

446

447

448

449

450

451

452

453

454

455

456

457

several mechanisms have been described (Allemand et al., 2011). The marked reduction in growth rate can be considered the main disadvantage over shallow farming locations such as lagoons. However, as it was the case in our study, the use of additional rearing levels at depth increased stocking capacity per nursery structure and could be an option to improve coral farming capacities and fragment output. Furthermore, the performance of outplanted colonies reared at different depths remains to be investigated.

To advance coral rearing success, fragment initial size should also be considered, although optimal size is likely species, method and location specific (Edwards \& Gomez, 2007; Edwards et al., 2010). Our results for $P$. verrucosa in the Maldives indicate that smaller fragments grew significantly faster. We used an average stocking size of about $5 \mathrm{~cm}$, with fragments ranging from 2.7 to $10 \mathrm{~cm}$ in maximum linear extension. In comparison, $P$. damicornis reared in rope nurseries in the Eastern Tropical Pacific exhibited a higher survival for fragments bigger than 2 $\mathrm{cm}$ but no significant difference in growth rate was found between size classes (Ishida-Castañeda et al., 2020).

Another interesting observation was that fragment genotypes deriving from 'reef-reared' donor colonies grew significantly faster in the RN as well as in the LN. One may expect that corals habituated to a particular environment may exhibit less stress after fragmentation if environmental conditions remain similar. Yet, we found that corals previously collected and farmed in the reef habitat generally outperformed fragments previously cultured in the lagoon, even after controlling for initial size. One noteworthy difference between donor colonies was initial rearing depth, which was generally deeper for 'reef-reared' donor colonies. Pocillopora is known to exhibit considerable environmental plasticity to adapt to variable conditions such as depth and water flow (Soto et al., 2019), but whether this could be a possible explanation for our observation and to what extent it is relevant to restoration practices remains to be further studied.

Finally, we observed some noteworthy points about nursery structure maintenance in our comparison of farming habitats. The removal of biofouling and sessile invertebrates typically constitutes a considerable workload and therefore cost factor in coral gardening (Precht, 2006). Algae were observed growing over the nursery structures in both habitats, especially at shallow depths. In the RN, overgrowth decreased noticeably with coral growing depth, likely as a result of reduced light, which reduces maintenance requirements. It has also been proposed that reef environments, home to a diverse community of herbivores and invertivores fish, can reduce nursery maintenance by providing a natural cleaning service and removing predators (Gochfeld \& Aeby, 1997; Frias-Torres et al., 2015; Frias-Torres \& van de Geer, 2015). While this study did not intend to investigate the contribution of natural cleaning services, the five-month forced maintenance pause provided some useful insight. No significant damage or overgrowth of the fragments occurred in either habitat, except for some Acropora spp. fragments growing at 5m on the $\mathrm{RN}$, that were in part overgrown by brown algae. 
458 It is also worth noting that the $\mathrm{LN}$ was placed further away from the island and daily resort

459

460

461

462

463

464

465

466

467

468

469

470

471

472

473

474

475

476

477

478

479

480

481

482

483

484

485

486

487

488

489

490

491

492

493

494

495

496

activities, which impeded accessibility but did not prevent, for example, disease occurrence. In contrast, the RN was located along a popular diving and snorkeling route on the easily accessible house reef, therefore benefitting from increased public awareness and support for the project.

We limited our study to branching and fast growing Acropora and Pocillopora species, which are suitable and commonly used genera for this restoration method (Levy et al., 2010; Mbije et al., 2010). They are also promising candidates for restoring habitat complexity, considering that these key genera have been disproportionally affected by the previous mass-bleaching events (Pisapia et al., 2017). However, additional species should be included in the future to increase species diversity and therefore resilience of restoration sites.

Although our study site represents a typical resort island, situated in one of the most popular Maldivian atolls (Statistical Yearbook of Maldives 2020), it should be considered that our findings are limited to a single location. Likewise, here we only assessed the first although important step of the coral gardening approach with research on the transplantation success of lagoon and reef reared corals to be conducted in the future. For instance, possible application advantages of reef rope nurseries for the transplantation phase could include more similar environmental conditions and shorter transportation to restoration sites.

Nevertheless, we hope to provide some new insight for restoration projects in the Maldives as such pilot studies are recommended to refine location and methods application (Shaver et al., 2020). In that way our study hopes to contribute by providing a sound assessment of mid-water rope nursery performance over a one-year study period in the Maldives and offers direct comparison of coral farming performance in a lagoon and reef habitat, which has not been conducted until now. As both nursery designs and habitats have been tested successfully, we suggest that Maldivian tourist resorts as well as local islands are suitable places for coral gardening projects, by the current standards of such endeavors and in a broader environmental management context (see Hein et al., 2021). Not only do they offer an opportunity to educate tourists and local on the immediate threat this ecosystem is facing, they also offer a 'hands-on' approach in the face of seemingly overwhelming climate change threats. In parallel, such projects can help to draw attention to local disturbances, for example tourism overuse or pollution, which are more likely to get addressed in the context of a local awareness and restoration project.

\section{Conclusions}

We conclude that reef and lagoon environments can provide suitable coral-farming habitats for mid-water rope nurseries in the Maldives, as our study demonstrated high survival and growth rates for Pocillopora and Acropora fragments over a one-year rearing period.

Peer) reviewing PDF | (2021:08:65161:2:0:NEW 4 Jan 2022) 
497 This provides a good starting point for the application of the coral gardening approach, although

498

499

500

501

502

503

504

505

506

507

508

509

510

511

512

513

514

515

516

517

518

519

520

521

522

523

524

525

526

527

528

529

530

531

532

533

534

535

536

increased species diversity should be included as a restoration goal. We also found some habitat and genus-specific differences, that are worth considering in future restoration projects. In direct comparison, the robust Pocillopora fragments performed better in a lagoon habitat and were less impacted by disease, while Acropora rearing success was better in the reef habitat. Smaller initial size $(<5 \mathrm{~cm})$ at stocking increases growth rates for Pocillopora in both habitats, while increased rearing depth decreases fragment growth. We suggest that mutualistic fauna, here more abundant in the lagoon, could be increased by stocking fragments together with older colonies to facilitate transmission. Furthermore, apart from fish predation, our mid-water rope nurseries provided good protection from corallivory in the lagoon and reef habitat. How different farming habitats and rearing depths translate into outplanting success of coral gardening remains to be tested. Finally, we consider reef mid-water rope nurseries a useful addition to the coral restoration tool kit in the Maldives, especially when lagoon farming habitats are not available, not easily accessible or conditions are unsuitable. Our streamlined rope nursery design withstood the high currents and fish abundance in the reef environment, while providing additional rearing space at depth. Therefore, we hope that this novel research provides some valuable insights for restoration practitioners and a step towards expanding restoration efforts in the Maldives.

\section{Acknowledgements}

The authors would like to thank Planhotel Hospitality Group, IDive Maldives, Athuruga Island watersports team and the families Trotman and Steiner for their support.

\section{References}

Allemand, D., Tambutté, E., Zoccola, D. \& Tambutté, S. (2011). Coral calcification, cells to reefs. In Coral Reefs: An Ecosystem in Transition, Z. Dubinsky \& N. Stambler (eds). Amsterdam, the Netherlands: Springer, 119-150.

Bayraktarov, E., Banaszak, A. T., Maya, P. M., Kleypas, J., Arias-Gonzalez, J. E., Blanco, M., Calle-Triviño, J., Charuvi, N., Cortes-Useche, C., Galvan, V., Salgado, M. A. G., Gnecco, M., Guendulain-Garcia, S. D., Delgado, E. A. H., Moraga, J. A. M., Maya, M. F., Quiroz, S. M., Cervantes, S. M., Morikawa, M., ... Frias-Torres, S. (2020). Coral reef restoration efforts in latin American countries and territories. PLoS ONE, 15(8), 1-19. https://doi.org/10.1371/journal.pone.0228477

Bellwood, D. R., Pratchett, M. S., Morrison, T. H., Gurney, G. G., Hughes, T. P., ÁlvarezRomero, J. G., Day, J. C., Grantham, R., Grech, A., Hoey, A. S., Jones, G. P., Pandolfi, J. M., Tebbett, S. B., Techera, E., Weeks, R., \& Cumming, G. S. (2019). Coral reef conservation in the Anthropocene: Confronting spatial mismatches and prioritizing functions. Biological Conservation, 236, 604-615. https://doi.org/10.1016/j.biocon.2019.05.056 
537

538

539

540

541

542

543

544

545

546

547

548

549

550

551

552

553

554

555

556

557

558

559

560

561

562

563

564

565

566

567

568

569

570

571

572

573

574

575

576

Boström-Einarsson, L., Babcock, R. C., Bayraktarov, E., Ceccarelli, D., Cook, N., Ferse, S. C. A., Hancock, B., Harrison, P., Hein, M., Shaver, E., Smith, A., Suggett, D., StewartSinclair, P. J., Vardi, T., \& McLeod, I. M. (2020). Coral restoration - A systematic review of current methods, successes, failures and future directions. PLoS ONE, 15(1). https://doi.org/10.1371/journal.pone.0226631

Castro, P. (1978). Movements between coral colonies in Trapezia ferruginea (Crustacea: Brachyura), an obligate symbiont of scleractinian corals. Marine Biology, 46(3), 237-245. https://doi.org/10.1007/BF00390685

Chase, T. J., Pratchett, M. S., Frank, G. E., \& Hoogenboom, M. O. (2018). Coral-dwelling fish moderate bleaching susceptibility of coral hosts. PLoS ONE, 13(12), 1-20. https://doi.org/10.1371/journal.pone.0208545

Chase, T. J., Pratchett, M. S., McWilliam, M. J., Hein, M. Y., \& Tebbett, S. B. Hoogenboom, M. O. (2020). Damselfishes alleviate the impacts of sediments on host corals. Royal Society Open Science, 7(4), 192074. http://doi.org/10.1098/rsos.192074

Clark, S., \& Edwards, A. J. (1994). Use of artificial reef structures to rehabilitate reef flats degraded by coral mining in the Maldives. Bulletin of Marine Science, 55(2-3), 724-744.

Clark, S., \& Edwards, A. J. (1995). Coral transplantation as an aid to reef rehabilitation: evaluation of a case study in the Maldive Islands. Coral Reefs, 14(4), 201-213. https://doi.org/10.1007/BF00334342

Connell, J. (1973). Population ecology of reef-building corals. In O. A. Jones \& R. Endean (Eds.), Biology and geology of coral reefs. Academic Press.

Duarte, C. M., Agusti, S., Barbier, E., Britten, G. L., Castilla, J. C., Gattuso, J. P., Fulweiler, R. W., Hughes, T. P., Knowlton, N., Lovelock, C. E., Lotze, H. K., Predragovic, M., Poloczanska, E., Roberts, C., \& Worm, B. (2020). Rebuilding marine life. Nature, 580(7801), 39-51. https://doi.org/10.1038/s41586-020-2146-7

Edwards, Alasdair J, \& Gomez, E. D. (2007). Reef Restoration Concepts and Guidelines: making sensible management choices in the face of uncertainty (E. D. Edwards, A.J., Gomez (Ed.)). Coral Reef Targeted Research \& Capacity Building for Management Programme. http://www.gefcoral.org/Portals/25/workgroups/rr_guidelines/rrg_fullguide.pdf

Edwards, Alasdair J, Guest, J., Shafir, S., Fisk, D., Gomez, E., Rinkevich, B., Heyward, A., Omori, M., Iwao, K., Dizon, R., Morse, A., Boch, C., Job, S., Bongiorni, L., Levy, G., Shaish, L., \& Wells, S. (2010). Reef Rehabilitation Manual (A.J. Edwards (Ed.)). The Coral Reef Targeted Research \& Capacity Building for Management Program. http://scholar.google.com/scholar?hl=en\&btnG=Search\&q=intitle:Reef+Rehabilitation + ma nual\#4

Epstein, N., Bak, R. P. M., \& Rinkevich, B. (2001). Strategies for Gardening Denuded Coral Reef Areas: The Applicability of Using Different Types of Coral Material for Reef Restoration. Restoration Ecology, 9(4), 432-442. https://doi.org/https://doi.org/10.1046/j.1526-100X.2001.94012.x

Forsman, Z. H., Rinkevich, B., \& Hunter, C. L. (2006). Investigating fragment size for culturing 
577

578

579

580

581

582

583

584

585

586

587

588

589

590

591

592

593

594

595

596

597

598

599

600

601

602

603

604

605

606

607

608

609

610

611

612

613

614

615

616

reef-building corals (Porites lobata and P. compressa) in ex situ nurseries. Aquaculture, 261(1), 89-97. https://doi.org/10.1016/j.aquaculture.2006.06.040

Foster, N. L., Baums, I. B., \& Mumby, P. J. (2007). Sexual vs. asexual reproduction in an ecosystem engineer: The massive coral Montastraea annularis. Journal of Animal Ecology, 76(2), 384-391. https://doi.org/10.1111/j.1365-2656.2006.01207.x

Fox, H. E., Harris, J. L., Darling, E. S., Ahmadia, G. N., \& Razak, T. B. (2019). Rebuilding coral reefs: success (and failure) 16 years after low-cost, low-tech restoration. Restoration ecology, 27(4), 862-869.

Frias-Torres, S., Goehlich, H., Reveret, C., \& Montoya-Maya, P. H. (2015). Reef fishes recruited at midwater coral nurseries consume biofouling and reduce cleaning time in Seychelles, Indian Ocean. African Journal of Marine Science, 37(3), 421-426. https://doi.org/10.2989/1814232X.2015.1078259

Frias-Torres, S., Montoya-Maya, P. H., \& Shah, N. (2018). Coral Reef Restoration Toolkit: A Field-Oriented Guide Developed in the Seychelles Islands (Sarah Frias-Torres, P. MontoyaMaya, \& N. Shah (Eds.)). Nature Seychelles, Mahe, Republic of Seychelles. https://doi.org/10.31230/osf.io/8eua9

Frias-Torres, S., \& van de Geer, C. (2015). Testing animal-assisted cleaning prior to transplantation in coral reef restoration. PeerJ, 2015(3), e1287. https://doi.org/10.7717/peerj.1287

Gladfelter, E.H., Monahan, R.K. \& Gladfelter, W.B. (1978). Growth rates of five reef- building corals in the northeastern Caribbean. Bulletin of Marine Science 28, 728-734.

Glynn, P. (1987). Some ecological consequences of coral-crustacean guard mutualisms in the Indian and Pacific Oceans. Symbiosis (Philadelphia, PA), 4(1), 301-323.

Gochfeld, D. J., \& Aeby, G. S. (1997). Control of populations of the coral-feeding nudibranch Phestilla sibogae by fish and crustacean predators. Marine Biology, 130(1), 63-69. https://doi.org/10.1007/s002270050225

Grigg, R. W. (2006). Depth limit for reef building corals in the Au'au Channel, SE Hawaii. Coral Reefs, 25(1), 77-84.0

Harris, D. L., Rovere, A., Casella, E., Power, H., Canavesio, R., Collin, A., Pomeroy, A., Webster, J. M., \& Parravicini, V. (2018). Coral reef structural complexity provides important coastal protection from waves under rising sea levels. Science Advances, 4(2), 18. https://doi.org/10.1126/sciadv.aao4350

Hein, M. Y., Birtles, A., Willis, B. L., Gardiner, N., Beeden, R., \& Marshall, N. A. (2019). Coral restoration: Socio-ecological perspectives of benefits and limitations. Biological Conservation, 229, 14-25. https://doi.org/10.1016/j.biocon.2018.11.014

Hein, M. Y., Vardi, T., Shaver, E. C., Pioch, S., Boström-Einarsson, L., Ahmed, M., Grimsditch, G., \& McLeod, I. M. (2021). Perspectives on the Use of Coral Reef Restoration as a Strategy to Support and Improve Reef Ecosystem Services. Frontiers in Marine Science, 8 , 299. https://doi.org/10.3389/fmars.2021.618303

Highsmith, R. (1982). Reproduction by Fragmentation in Corals. Marine Ecology Progress 
617

618

619

620

621

622

623

624

625

626

627

628

629

630

631

632

633

634

635

636

637

638

639

640

641

642

643

644

645

646

647

648

649

650

651

652

653

654

655

656

Series, 7(4), 207-226. https://doi.org/10.3354/meps007207

Huston, M. (1985). Variation in coral growth rates with depth at Discovery Bay, Jamaica. Coral Reefs 4, 19-25.

Ibrahim, N., Mohamed, M., Basheer, A., Ismail, H., Nistharan, F., Schmidt, A., Naeem, R., Abdulla, A., \& Grimsditch, G., (2017). Status of Coral Bleaching in the Maldives in 2016. Marine Research Centre, Malé, Maldives

Ishida-Castañeda, J., Pizarro, V., López-Victoria, M., \& Zapata, F. A. (2020). Coral reef restoration in the Eastern Tropical Pacific: feasibility of the coral nursery approach. Restoration Ecology, 28(1), 22-28. https://doi.org/10.1111/rec.13047

Jaleel, A. (2013). The status of the coral reefs and the management approaches: Thecase of the Maldives. Ocean and Coastal Management, 82, 104-118. https://doi.org/10.1016/j.ocecoaman.2013.05.009

Koval, G., Rivas, N., D’Alessandro, M., Hesley, D., Santos, R., \& Lirman, D. (2020). Fish predation hinders the success of coral restoration efforts using fragmented massive corals. PeerJ, 8, 1-20. https://doi.org/10.7717/peerj.9978

Levy, G., Shaish, L., Haim, A., \& Rinkevich, B. (2010). Mid-water rope nursery-Testing design and performance of a novel reef restoration instrument. Ecological Engineering, 36(4), 560-569. https://doi.org/10.1016/j.ecoleng.2009.12.003

Masselink, G., Beetham, E., \& Kench, P. (2020). Coral reef islands can accrete vertically in response to sea level rise. Science Advances, 6(24). https://doi.org/10.1126/sciadv.aay3656

Mbije, N. E. J., Spanier, E., \& Rinkevich, B. (2010). Testing the first phase of the "gardening concept" as an applicable tool in restoring denuded reefs in Tanzania. Ecological Engineering, 36(5), 713-721. https://doi.org/10.1016/j.ecoleng.2009.12.018

McKeon, C. S., \& Moore, J. M. (2014). Species and size diversity in protective services offered by coral guard-crabs. PeerJ, 2014(1), 1-15. https://doi.org/10.7717/peerj.574

Miller, M. W., Marmet, C., Cameron, C. M., \& Williams, D. E. (2014). Prevalence, consequences, and mitigation of fireworm predation on endangered staghorn coral. Marine Ecology Progress Series, 516, 187-194. https://doi.org/10.3354/meps 10996

Montalbetti, Enrico, Saponari, L., Montano, S., Maggioni, D., Dehnert, I., Galli, P., \& Seveso, D. (2019). New insights into the ecology and corallivory of Culcita sp. (Echinodermata: Asteroidea) in the Republic of Maldives. Hydrobiologia, 827(1), 353-365. https://doi.org/10.1007/s10750-018-3786-6

Montano, S., Strona, G., Seveso, D., Maggioni, D., \& Galli, P. (2016). Widespread occurrence of coral diseases in the central Maldives. Marine and Freshwater Research, 67(8), 1253-1262. https://doi.org/10.1071/MF14373

Montano, S., Fattorini, S., Parravicini, V., Berumen, M. L., Galli, P., Maggioni, D., ... \& Strona, G. (2017). Corals hosting symbiotic hydrozoans are less susceptible to predation and disease. Proceedings of the Royal Society B: Biological Sciences, 284(1869), 20172405.

Moriarty, T., Leggat, W., Huggett, M. J., \& Ainsworth, T. D. (2020). Coral Disease Causes, Consequences, and Risk within Coral Restoration. Trends in Microbiology, 28(10), 793- 
657

658

659

660

661

662

663

664

665

666

667

668

669

670

671

672

673

674

675

676

677

678

679

680

681

682

683

684

685

686

687

688

689

690

691

692

693

694

695

696

807. https://doi.org/10.1098/rspb.2017.2405

Morrison, T. H., Adger, N., Barnett, J., Brown, K., Possingham, H., \& Hughes, T. (2020). Advancing Coral Reef Governance into the Anthropocene. One Earth, 2(1), 64-74. https://doi.org/10.1016/j.oneear.2019.12.014

Naseer, A., \& Hatcher, B. G. (2004). Inventory of the Maldives' coral reefs using morphometrics generated from Landsat ETM+ imagery. Coral Reefs, 23(1), 161-168. https://doi.org/10.1007/s00338-003-0366-6

Perry, C. T., \& Morgan, K. M. (2017). Bleaching drives collapse in reef carbonate budgets and reef growth potential on southern Maldives reefs. Scientific Reports, 7(1), 1-9. https://doi.org/10.1038/srep40581

Pisapia, C., El Kateb, A., Hallock, P., \& Spezzaferri, S. (2017). Assessing coral reef health in the North Ari Atoll (Maldives) using the FoRAM Index. Marine Micropaleontology, 133, 5057. https://doi.org/10.1016/j.marmicro.2017.06.001

Pisapia, C., Burn, D., \& Pratchett, M. S. (2019). Changes in the population and community structure of corals during recent disturbances (February 2016-October 2017) on Maldivian coral reefs. Scientific reports, 9(1), 1-12. https://doi.org/10.1038/s41598-019-44809-9

Precht, W. F. (2006). Coral reef restoration handbook. CRC press.

Rinkevich, B. (1995). Restoration Strategies for Coral Reefs Damaged by Recreational Activities: The Use of Sexual and Asexual Recruits. Restoration Ecology, 3(4), 241-251. https://doi.org/10.1111/j.1526-100X.1995.tb00091.x

Rinkevich, B. (2000). Steps towards the evaluation of coral reef restoration by using small branch fragments. Marine Biology, 136(5), 807-812. https://doi.org/10.1007/s002270000293

Saponari, L., Dehnert, I., Galli, P., \& Montano, S. (2021). Assessing population collapse of Drupella spp. (Mollusca: Gastropoda) 2 years after a coral bleaching event in the Republic of Maldives. Hydrobiologia, 848(11), 2653-2666. https://doi.org/10.1007/s10750-02104546-5

Saponari, L., Montalbetti, E., Galli, P., Strona, G., Seveso, D., Dehnert, I., \& Montano, S. (2018). Monitoring and assessing a 2-year outbreak of the corallivorous seastar Acanthaster planci in Ari Atoll, Republic of Maldives. Environmental Monitoring and Assessment, 190(6), 344. https://doi.org/10.1007/s10661-018-6661-z

Schopmeyer, S. A., Lirman, D., Bartels, E., Gilliam, D. S., Goergen, E. A., Griffin, S. P., Johnson, M. E., Lustic, C., Maxwell, K., \& Walter, C. S. (2017). Regional restoration benchmarks for Acropora cervicornis. Coral Reefs, 36(4), 1047-1057. https://doi.org/10.1007/s00338-017-1596-3

Seraphim, M. J., Sloman, K. A., Alexander, M. E., Janetski, N., Jompa, J., Ambo-Rappe, R., Snellgrove, D., Mars, F., \& Harborne, A. R. (2020). Interactions between coral restoration and fish assemblages: implications for reef management. Journal of Fish Biology 97(3), 633-655. https://doi.org/10.1111/jfb.14440

Shafir, S., \& Rinkevich, B. (2010). Integrated long term mid-water coral nurseries: A 
697

698

699

700

701

702

703

704

705

706

707

708

709

710

711

712

713

714

715

716

717

718

719

720

721

722

723

724

725

726

727

728

729

730

731

732

733

734

735

736

management instrument evolving into a floating ecosystem. University of Mauritius Research Journal, 16, 365-386.

Shafir, S., Van Rijn, J., \& Rinkevich, B. (2006). Steps in the construction of underwater coral nursery, an essential component in reef restoration acts. Marine Biology, 149(3), 679-687. https://doi.org/10.1007/s00227-005-0236-6

Shaver, E. C., Courtney, C. A., West, J. M., Maynard, J., Hein, M., Wagner, C., Philibotte, J., MacGowan, P., McLeod, I., Boström-Einarsson, L., Bucchianeri, K., Johnston, L., \& Koss, J. (2020). A Manager's Guide for Coral Reef Restoration Planning \& Design. https://repository.library.noaa.gov/view/noaa/27219

Soong, K., \& Chen, T. (2003). Coral Transplantation: Regeneration and Growth of Acropora Fragments in a Nursery. Restoration Ecology, 11(1), 62-71. https://doi.org/10.1046/j.1526100X.2003.00100.X

Soto, D., De Palmas, S., Ho, M. J., Denis, V., \& Chen, C. A. (2019). Spatial variation in the morphological traits of Pocillopora verrucosa along a depth gradient in Taiwan. PLoS ONE, 13(8), 1-20. https://doi.org/10.1371/journal.pone.0202586

Sovacool, B. K. (2012). Expert views of climate change adaptation in the Maldives. Climatic Change, 114(2), 295-300. https://doi.org/10.1007/s10584-011-0392-2

Statistical Yearbook of Maldives. (2020). http://statisticsmaldives.gov.mv/yearbook/2020/

Stewart, H. L., Holbrook, S. J., Schmitt, R. J., \& Brooks, A. J. (2006). Symbiotic crabs maintain coral health by clearing sediments. Coral Reefs, 25(4), 609-615. https://doi.org/10.1007/s00338-006-0132-7

Stier, A. C., \& Leray, M. (2014). Predators alter community organization of coral reef cryptofauna and reduce abundance of coral mutualists. Coral Reefs, 33(1), 181-191. https://doi.org/10.1007/s00338-013-1077-2

Storlazzi, C. D., Gingerich, S. B., Van Dongeren, A., Cheriton, O. M., Swarzenski, P. W., Quataert, E., Voss, C. I., Field, D. W., Annamalai, H., Piniak, G. A., \& McCall, R. (2018). Most atolls will be uninhabitable by the mid-21st century because of sea-level rise exacerbating wave-driven flooding. Science Advances, 4(4), 1-10. https://doi.org/10.1126/sciadv.aap9741

Tkachenko, K. S. (2015). Impact of repetitive thermal anomalies on survival and development of mass reef-building corals in the Maldives. Marine Ecology, 36(3), 292-304. https://doi.org/https://doi.org/10.1111/maec.12138

United Nations Environment Assembly (UNEA). (2019). Report of the second session of the United Nations Environment Assembly of the United Nations Environment Programme (Issue Fourth Session, 11-15 March). https:/www.un.org/ecosoc/sites/www.un.org.ecosoc/files/files/en/cmm/k1606792-uneareport.pdf

Williams, S. L., Sur, C., Janetski, N., Hollarsmith, J. A., Rapi, S., Barron, L., ... \& Mars, F. (2019). Large-scale coral reef rehabilitation after blast fishing in Indonesia. Restoration Ecology, 27(2), 447-456. 


\section{Table $\mathbf{1}$ (on next page)}

Coral nursery performance of Pocillopora verrucosa.

The table shows fragment survival, disease incidents, predation and associated fauna rate (average rate of affected fragments per survey), Ecological volume (EV) size augmentation and daily growth rates after a one-year farming period ( $T 7=371$ days) for the different study groups reared in mid-water rope nurseries in a lagoon (LN) and reef (RN) habitat at different depths. 


\begin{tabular}{|c|c|c|c|c|c|c|c|c|c|c|}
\hline Group & $\begin{array}{l}\text { Nursery } \\
\text { Habitat }\end{array}$ & $\begin{array}{l}\text { Depth } \\
\text { (m) }\end{array}$ & $\begin{array}{c}\text { No. of } \\
\text { Fragments }\end{array}$ & $\begin{array}{c}\text { Stocking } \\
\text { Period } \\
\text { (days at T7) }\end{array}$ & $\begin{array}{l}\text { Survival } \\
\text { (\% at T7) }\end{array}$ & $\begin{array}{l}\text { Disease } \\
\text { (\% at T7) }\end{array}$ & $\begin{array}{l}\text { Predation Rate } \\
(\text { mean } \% \pm \mathrm{SE})\end{array}$ & $\begin{array}{c}\text { Fauna } \\
\text { Occurrence } \\
(\text { mean } \% \pm \text { SE) }\end{array}$ & $\begin{array}{c}\text { EV Size } \\
\text { Augmentation } \\
\left(\mathrm{cm}^{3} \text { at } \mathrm{T} 7 \pm \mathrm{SE}\right)\end{array}$ & $\begin{array}{c}\text { Daily Growth } \\
\text { Rate } \\
\text { (at } \mathrm{T} 7 \pm \mathrm{SE} \text { ) }\end{array}$ \\
\hline Poc_LN_5m & Lagoon & 5 & 112 & 371 & $99.11^{* *}$ & 0 & $37.19 \pm 18.14$ & $25.64 \pm 6.83 * * *$ & $863.60 \pm 29.99$ & $0.08 \pm .005$ \\
\hline Poc_RN_5m & Reef & 5 & 112 & 371 & 90.18 & 2.97 & $58.64 \pm 15.56^{* * *}$ & $11.48 \pm 3.10$ & $739.74 \pm 5.17$ & $0.07 \pm .004$ \\
\hline Poc_RN_10m & Reef & 10 & 112 & 371 & 91.07 & 5.88 & $48.66 \pm 13.78$ & $4.46 \pm 1.28$ & $539.14 \pm 20.55$ & $0.05 \pm .003 * * *$ \\
\hline Poc_RN_15m & Reef & 15 & 112 & 371 & 94.64 & 1.89 & $39.75 \pm 15.45^{* * *}$ & $5.23 \pm 1.51$ & $386.31 \pm 13.56$ & $0.04 \pm .002 * *$ \\
\hline & & & & & & & & & & \\
\hline & & & & & & & 然 & & & \\
\hline Poc_all & all & all & 448 & 371 & 93.75 & 2.62 & $52.63 \pm 15.45$ & $11.70 \pm 3.10$ & $634.56 \pm 14.73$ & $0.06 \pm .002$ \\
\hline
\end{tabular}

7 Significance levels: $* * *<0.001, * *<0.01$ and $*<0.05$

8 


\section{Table 2 (on next page)}

Coral nursery performance of Acropora spp..

The table shows fragment survival, disease incidents, predation and associated fauna rate (average rate of affected fragments per survey), Ecological volume (EV) size augmentation and daily growth rates after a one-year farming period (T7=353 days) for the different study groups reared in mid-water rope nurseries in a lagoon (LN) and reef (RN) habitat. 


\begin{tabular}{|c|c|c|c|c|c|c|c|c|c|c|}
\hline Group & $\begin{array}{l}\text { Nursery } \\
\text { Habitat }\end{array}$ & $\begin{array}{l}\text { Depth } \\
\text { (m) }\end{array}$ & $\begin{array}{c}\text { No. of } \\
\text { Fragments }\end{array}$ & $\begin{array}{c}\text { Stocking } \\
\text { Period } \\
\text { (days at T7) }\end{array}$ & $\begin{array}{l}\text { Survival } \\
(\% \text { at } \mathrm{T} 7)\end{array}$ & $\begin{array}{l}\text { Disease } \\
(\% \text { at } \mathrm{T} 7)\end{array}$ & $\begin{array}{c}\text { Predation } \\
(\mathrm{mean} \% \pm \mathrm{SE})\end{array}$ & $\begin{array}{c}\text { Fauna } \\
(\text { mean } \% \pm \mathrm{SE})\end{array}$ & $\begin{array}{c}\text { EV Size } \\
\text { Augmentation } \\
\left(\mathrm{cm}^{3} \text { at } \mathrm{T} 7 \pm \mathrm{SE}\right)\end{array}$ & $\begin{array}{c}\text { Daily Growth } \\
\text { Rate } \\
\text { (at } \mathrm{T} 7 \pm \mathrm{SE} \text { ) }\end{array}$ \\
\hline Acr_LN_5m & Lagoon & 5 & 48 & 353 & $81.25^{*}$ & 17.95 & 0 & $22.62 \pm 5.40$ & $254.50 \pm 35,23$ & $0.02 \pm .002 * *$ \\
\hline Acr_RN_5m & Reef & 5 & 48 & 353 & $95.83^{*}$ & 0 & $0.62 \pm 0.67$ & $3.87 \pm 2.36$ & $353.84 \pm 38.23$ & $0.04 \pm .006^{* *}$ \\
\hline Acr_total & all & 5 & 96 & 353 & 88.54 & 8.24 & $0.32 \pm 0.35$ & $13.24 \pm 3.61$ & $308.90 \pm 26.72$ & $0.03 \pm .003$ \\
\hline
\end{tabular}

$7 \quad$ Significance levels: $* * *<0.001, * *<0.01$ and $*<0.05$ 


\section{Figure 1}

Study location and mid-water rope nursery design.

(A) Map showing the Republic of Maldives, where Athuruga Resort Island ( $3^{\circ} 53^{\prime} 14^{\prime \prime} \mathrm{N}$ $72^{\circ} 48^{\prime} 59^{\prime \prime} \mathrm{E}$ ) is located in the center of Alif Dhaal atoll (scale bar: $1 \mathrm{~km}$; island in black, reef in grey, water in white). (B) Lagoon mid-water rope nursery (LN) adjusted from Levy et al. (2010) measuring $3 \mathrm{~m}$ in width and $10 \mathrm{~m}$ in length at coral rearing level at $5 \mathrm{~m}$ water depth. The main structure consists of 3 PVC pipes, connected with $10 \mathrm{~mm}$ rope to the anchoring iron bars and air-filled buoyancy containers pulling the structure upwards. (C) Reef mid-water rope nursery (RN) with adjusted streamline design, build parallel to the reef and anchored at $20 \mathrm{~m}$ depth. Coral ropes are attached at 3 different depth levels $(5,10$ and $15 \mathrm{~m})$. 


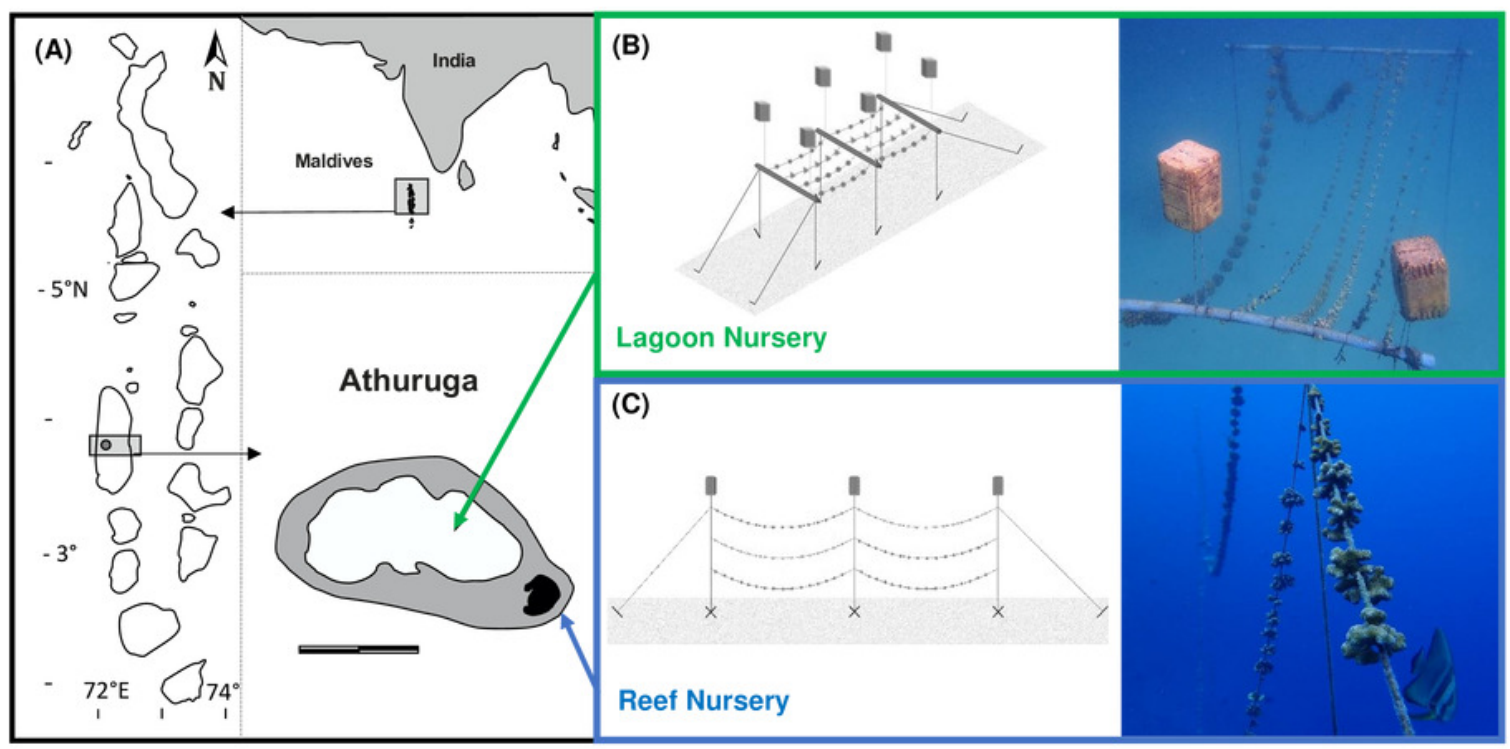




\section{Figure 2}

Categories for coral fragment assessment.

A) $\mathrm{H} 1$ : less than $50 \%$ tissue alive. (B) $\mathrm{H} 2$ : more than $50 \%$ tissue alive. (C) $\mathrm{H} 3$ : $100 \%$ tissue alive; arrow indicates a guard crab Trapezia sp. (D) 100\% mortality. (E) 'White syndrome' diseased fragment. $(\mathrm{F})$ fish predation and fresh predation marks. $1 \mathrm{~cm}$ white scale bars (photos by I. Dehnert).

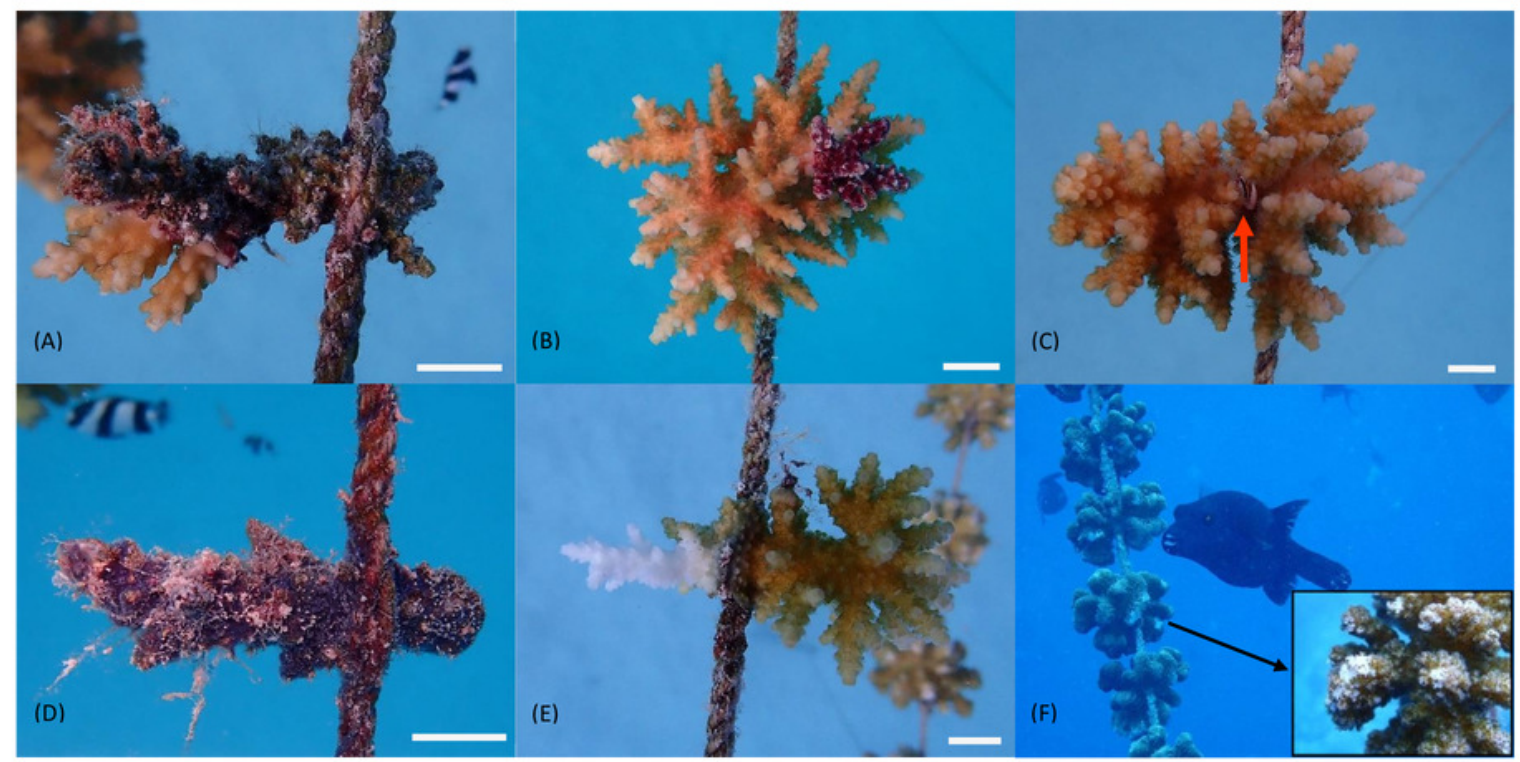




\section{Figure 3}

Condition of coral fragments after one year.

The figure shows four groups of Pocillopora verrucosa (Poc) and two groups of Acropora spp. (Acr) growing in a lagoon (LN) and a reef (RN) mid-water rope nursery at different depths for one year (T7).

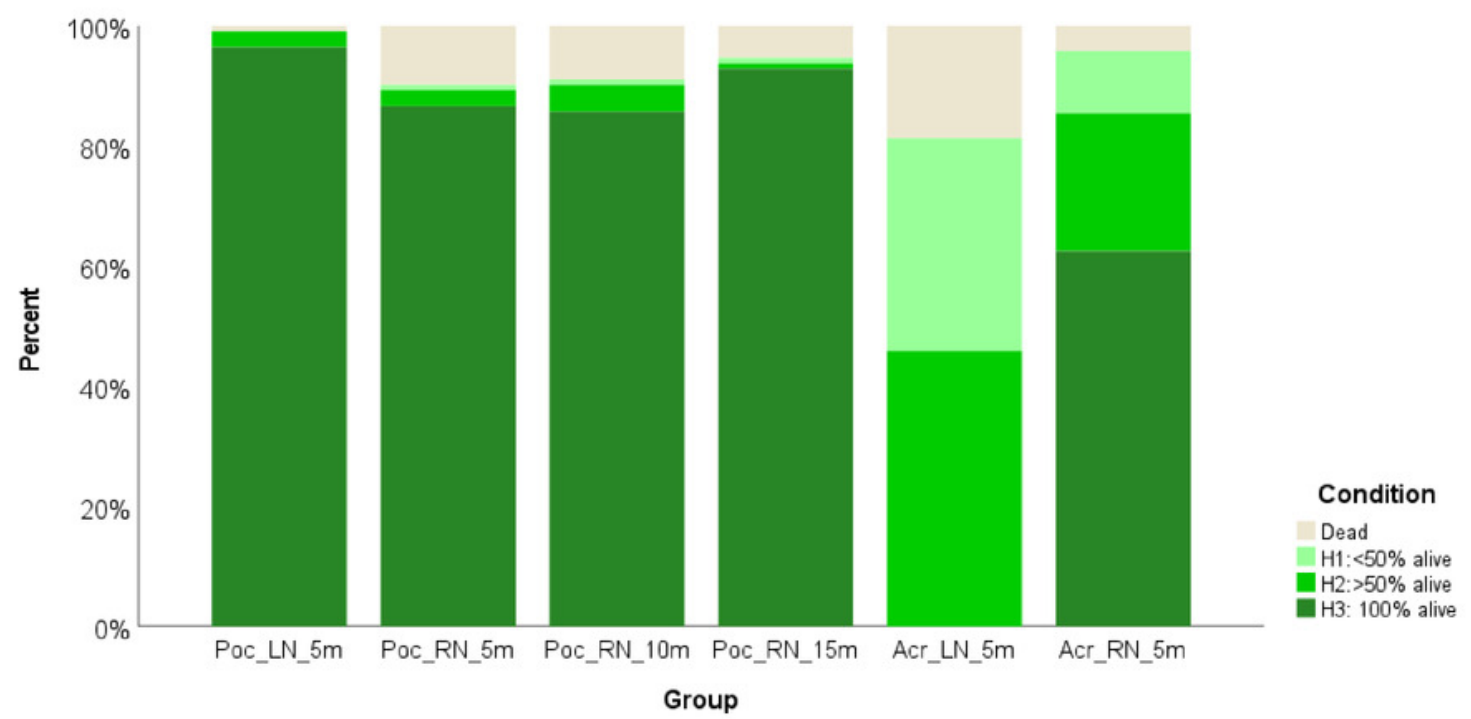


Figure 4

Coral Ecological Volume increase over one year.

The graphs show mean Ecological Volume (EV) at three different times (T0, T3, T7) during the one-year study period in a reef (RN) and a lagoon (LN) mid-water rope nursery for (A) $P$. verrucosa (Poc) fragments at different depths and (B) Acropora spp. (Acr) fragments at $5 \mathrm{~m}$ depth. Error Bars: +/- 2 SE.
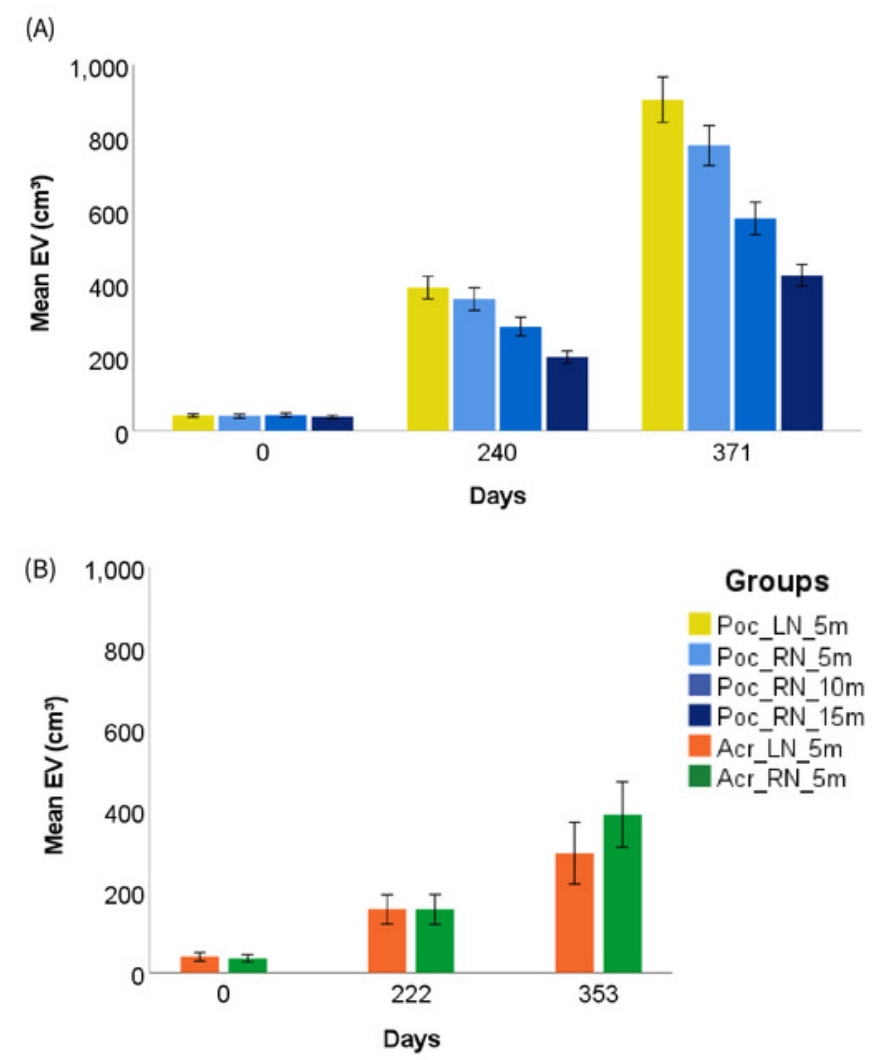
Figure 5

Correlation between Pocillopora verrucosa fragment stocking size and growth.

The scatterplot shows a significant negative correlation between fragment Ecological Volume $(\mathrm{EV})$ at $\mathrm{TO}$ and the $\mathrm{EV}$ daily growth rate at $\mathrm{T7}(r(418)=-0.56 ; p<0.001)$. A linear regression line was fitted for each group (LN_5m: $R_{\text {Linear }}^{2}=0.42 ; R N \_5 m: R_{\text {Linear }}^{2}=0.42 ; R N \_10 m$ : $\left.\mathrm{R}_{\text {Linear }}=0.40 ; \mathrm{RN}_{-} 15 \mathrm{~m}: \mathrm{R}_{\text {Linear }}=0.46\right)$.

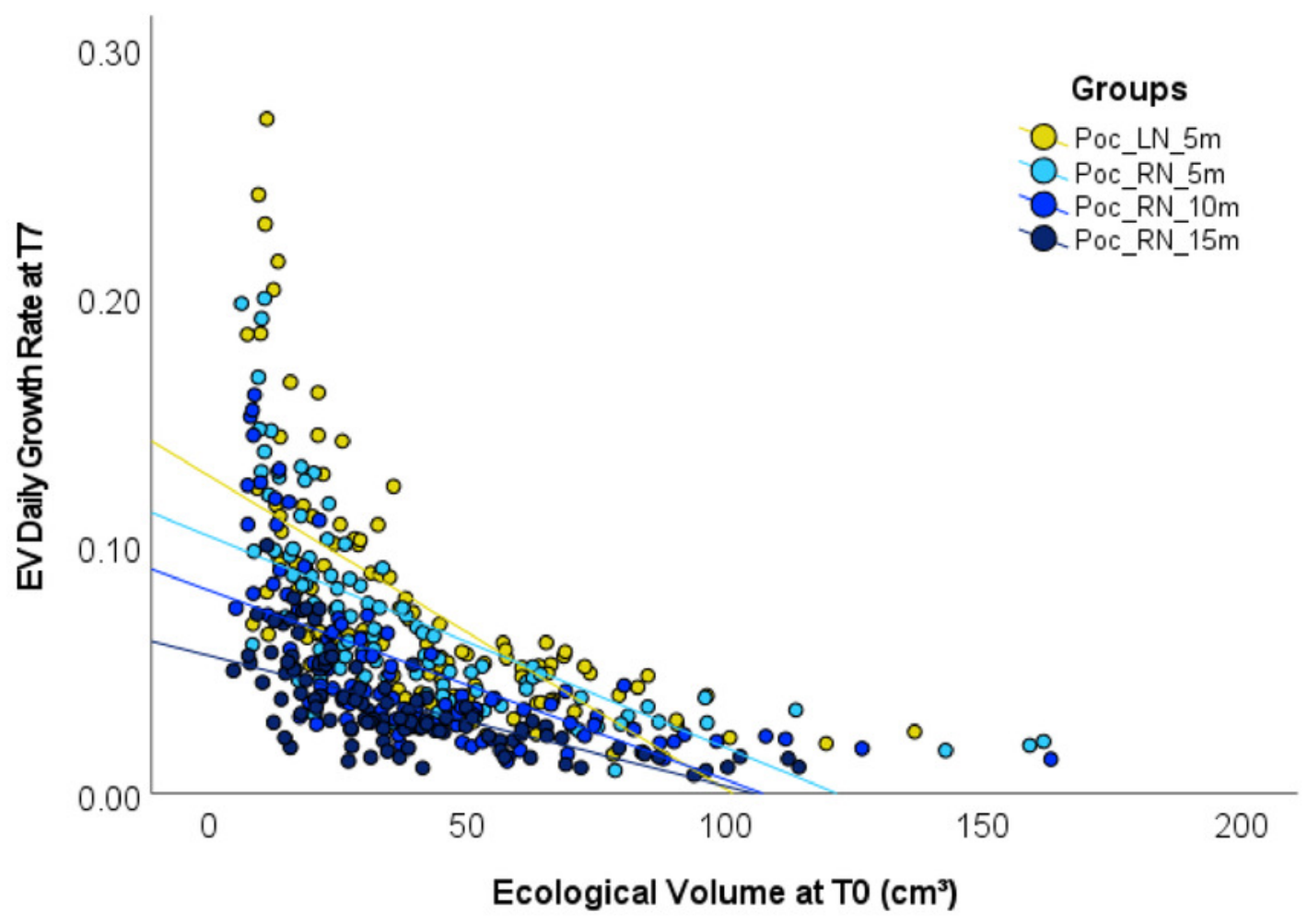




\section{Figure 6}

Growth rate comparison of Pocillopora verrucosa fragments from different donor farming habitats for each study group.

The boxplots show the comparison fragments within each study group (LN 5, RN5, RN10 and RN15), originating from different donors that were previously grown in either the 'lagoon' or the 'reef' farming habitat. Fragments derived from reef nursery reared donor colonies grew significantly faster in the lagoon nursery and at 10 and $15 \mathrm{~m}$ depth in the reef nursery.

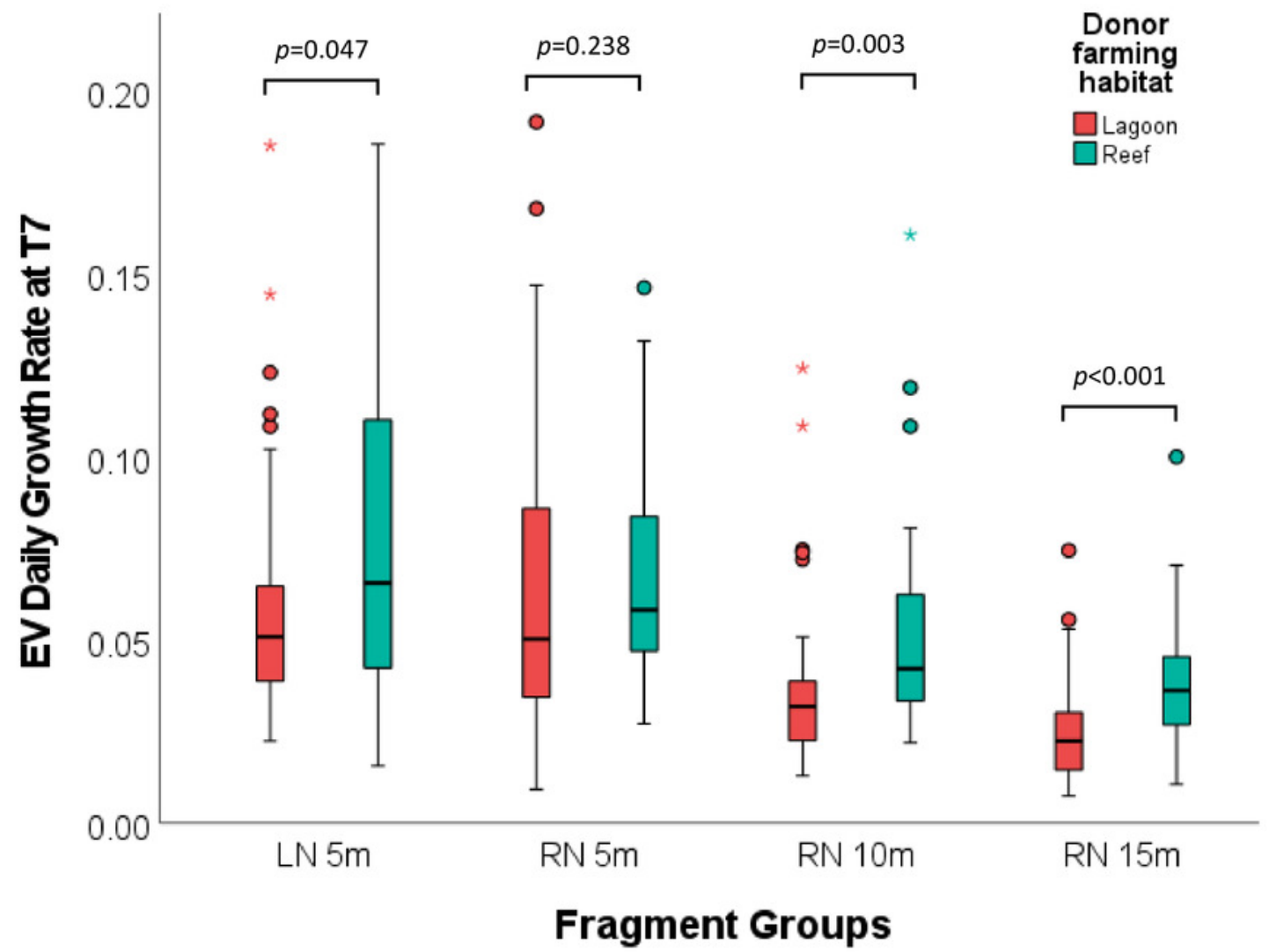

